Johann Heiss and Eirik Hovden

\title{
Zaydī Theology Popularised: A Hailstorm Hitting the Heterodox
}

This article examines the apocalyptic interpretation of natural phenomena in Islam, analyzing the religious and political aspects of a story about a hailstorm hitting a village in the southwest corner of the Arabian Peninsula sometime around 1205-1210. According to certain contemporary Zaydi interpretations, through this catastrophe God was directly intervening in order to punish the followers of a sub-branch of Zaydism in Yemen, the so-called Muțarrifiyya. Whereas the Zaydī imam al-Manșūr 'Abdallāh b. Hamza and his followers argued that God would repeatedly intervene in the natural world, statements ascribed to the Mutarrifiyya assert that he would only start the process of creation, with the physical world transforming itself on a continuous basis thereafter. Because the imam and his followers would interpret natural phenomena as signs sent by God, the hailstorm was considered to be a punishment of the village's inhabitants, the Mutarrifis, who subscribed to practising the wrong creed. After having met their resistance, the imam had declared previously the Mutarrifis to be unbelievers. In doing so, he used the imagery of the End Times to legitimise his attack and the confiscation of their property. This article analyses in detail the story about the hailstorm, which was written by a secretary of the imam, and connects it to other contemporary texts. It demonstrates how scholarly categories of theology and cosmology were popularised and politicised in order to create communities and hierarchies and to draw boundaries of inclusion and exclusion.

Perceptions about the End Times in the Muslim world ${ }^{1}$ usually include stories about catastrophes and vicissitudes announcing the end. ${ }^{2}$ The Qur'an, for example, is full of mentions "of death, the end of the world, and resurrection". ${ }^{3}$ Events announcing the End Times are alluded to in sura 81, called "al-Takwīr" or, "the folding up". Verse $1-14$ of the sura reads, using anaphors and end-rhymes:

When the sun is rolled up,

and when the stars swoop down,

1 On eschatological and apocalyptic ideas in the Muslim World see Günther and Lawson, eds., Roads to Paradise; Chittick, "Muslim Eschatology;" Smith and Haddad, The Islamic Understanding of Death and Resurrection.

2 See for instance Chittick, "Muslim Eschatology," 133.

3 Chittick, "Muslim Eschatology," 132

Note: Research for this article was funded by the SFB Visions of Community (Austrian Science Fund FWF F42-G18) and partly by the HERA project, “Uses of the Past: Understanding Shari'a: Custom, Gender State and Violence", usppip (www.usppip.eu).

๖ Open Access. (C) 2020 Johann Heiss, Eirik Hovden, published by De Gruyter. $\leftrightarrow$ BY-NC-ND This work is licensed under the Creative Commons Attribution-NonCommercial-NoDerivatives 4.0 License.

https://doi.org/10.1515/10.1515/9783110597745-016 
and when the mountains are moved, and when the camels about to give birth are left untended, and when the beasts are gathered together, and when the seas boil over, and when the humans are coupled [sc. with their bodies], and when the girl that was buried is made to ask for what crime she had been killed, and when the leaves [of men's deeds] are unfolded, and when heaven is pulled off, and when hellfire is kindled, and when paradise is brought close: every human will come to know what he has brought along. ${ }^{4}$

Some of the events mentioned in this sura relate to natural disasters. Sufficient rain is fundamental for agriculture, but too much rain can wreck agricultural infrastructure such as terraces or canals within minutes. Meteorological incidents, such as too little or too much rain at the wrong time of the year, could be seen as signs of the coming of yawm al-qiyāma, the Day of Resurrection. ${ }^{5}$ Rain and weather is a topic that can make theology relevant for the farmers: rain invocations (istisq $\bar{a}$, istighätha) have been a continuous feature in the cultural history of South Arabia from pre-Islamic times until today. ${ }^{6}$ On the way from high-level theology to farmers' practical spell, the logic changes, and the words used may take on new meanings. The way natural events were interpreted could vary significantly according to different worldviews and political positions. ${ }^{7}$

This article is about how theology and cosmology, which tended to be important forms of knowledge reserved to elite scholars in religious establishments, were transformed into populist narratives and political slogans that everyone could relate to and rally behind. Thus this chapter is also about how complex theological discourses are made known and comprehensible to a wider audience, and how they can be given political potency.

The article analyses the occurrence and religious/political interpretations of allegedly extreme weather-conditions in the south-east of the Arabian Peninsula. According to mainstream Zaydī interpretations, God interfered directly in nature and punished a sub-branch of Zaydism in Yemen, named the "Mutarrifiyya", ${ }^{8}$ with a

4 The translation follows Muhammad Asad's in changed form.

5 Books on the End Times in Arabic Islamic literature exists in numbers, as an example: Abū Ḥāmid al-Ghazālī (d. 1111), al-Durra al-fākhira fì kashf 'ulūm al-ākhira ("The Precious Pearl about the Unveiling of the Knowledge of the End"), ed. Gautier [orig. 1878].

6 For the rain invocation or "Regenopfer" (called istighätha in the north of Yemen) see Gingrich, Erkundungen, 112-113; Varisco, "The Adaptive Dynamics of Water Allocation in Al-Ahjur, Yemen Arab Republic," 104-107.

7 For an overview, see Heiss and Hovden, "Competing Visions of Community in Medieval Zaydī Yemen," 366-307.

8 Madelung, "Muțarrifiyya." 
hailstorm that struck a specific village in the Yemeni highlands sometime around 1205-1210: ${ }^{9}$

The Muțarrifiyya, as far as we know about their creed, claim that anyone who wants to be a prophet can be so, the only exception being his incapacity. Thus they exceed the unbelief of the Banū Hanīifa ${ }^{10}$ and others of the unbelievers (kuffär) [...].

When the "judgement of the sword"11 had been passed on the Mutarrifiyya by the imam, peace be upon him, Rāshid b. Muhammad al-Ṣaqrī al-Janbīi ${ }^{12}$ refused to acknowledge it. In those days, he stayed in the region of al-Ahnum where his influence was already established in its plains and mountains. He had propagated the school ${ }^{13}$ of the Mutarrifiyya there and most of the inhabitants sympathised with it.

He [al-Ṣaqrī] was the shaykh of the 'the people of the strike' who maintain that God created the world in one strike (qafakha) and made some parts of it as a causation for other parts, and that God has no longer any direct role in his creation, so for him [God] no activity is left in his creation.

He [al-Ṣaqrī] called for a meeting for everyone at a place called al-Ḥuraymāt of the land of Banū 'Abd al-'Azīz of the region al-Ahnūm. He described to them what had happened to his fellow Muțarrifis regarding punishment, killing and confiscation of properties. He called for patience and perseverance in favour of their school ${ }^{14}$, for the defense of their religion and the keeping of their creed. He aroused their feelings for fighting the imam, peace be on him, and they [the local people] responded positively.

They had not yet dispersed again from their meeting place when God the Exalted caused a cloud to rise, and from that cloud pelted them with a punishment never seen at that time. A violent wind with ice/hail came down on them, which did not go beyond the borders of the village where they had met. It destroyed the agricultural lands and uprooted the crops, the wines, the trees and the fruits.

It was a clear $\operatorname{sign} n^{15}$ for the people of that village; they saw in it an evil omen and they knew that they had been hit with His intention.

The ice remained on those trees that were left in that area for three days. A group of the local population repented and recognised the greatness of the imam, peace be on him. After that, this evil one [al-Ṣaqrī] stayed on for some days. Then they expelled him from their lands.

The author of al-Sīra al-sharīfa al-Manșūriyy ("The Illustrious Manșūrī Biography”), the biography of Imam al-Manșūr bi-Llāh 'Abdallāh b. Hamza (r. 1197-d. 1217), was Abū Firās b. Di'tham, the imam's kātib al-inshā' or chief secretary. His duties in-

9 All dates in this article refer to CE. The following story is taken from Abū Firās ibn Di'tham's alsīra al-sharīfa al-Manșūrīya, 852-853.

10 This is an allusion to the story of Musaylima al-kadhdhāb, the "false" prophet, and the Banū Ḥanifa who were his adherents. He was a contemporary of the prophet Muhammad and ever since has been a famous figure in later literature used to represent false claims to religion.

11 Ar. hukm al-sayf, the death-sentence; as a precondition for the hukm al-sayf, the members of the Muțarrifiyya had to be declared unbelievers (takfir).

12 At that time a leading Muțarrifí, mentioned three times in the biography of 'Abdallāh b. Ḥamza; the vocalization is not certain.

13 Ar. madhhab, usually a school of thought in fiqh, here used for a group of heretics.

14 The author uses the word madhhab again.

15 Ar. àya zāhira. 
cluded the composition of the imam's letters, documents, and treaties, and the reading of all incoming mail. He was thus in an ideal position to write a biography of his master; in addition, he was also an accomplished poet. Ibn Di'tham originated from a family of Sanaa, some of whose members had already been secretaries. Ahmad b. Șālih b. Abī l-Rijāl (d. 1681), who included Abū Firās b. Di'tham in his biographical dictionary Mațla' al-budūr wa-majma' al-buhūur ${ }^{16}$, calls him a "sword drawn against the Muṭarrifiyya" ${ }^{17}$. Ibn Abī l-Rijāl completed his biography of Ibn Di'tham with exemplary verses of his poems, and cites the end of the biography of Imam al-Manșūr 'Abdallāh b. Hamza. The passage quoted, in a high rhetorical style and in rhymed prose $\left(s a j^{\prime}\right)$, contains the only date known concerning Ibn Di'tham: He ended his work in June 1218, just little more than a year after his master's death.

Ibn Di'tham's work, the biography of Imam al-Manșūr 'Abdallāh b. Hamza, originally consisted of four volumes. Only the second (now in the Biblioteca Ambrosiana, Milan) and the third volume (now in Sanaa, Great Mosque) are preserved. ${ }^{18}$ They were edited by 'Abd al-Ghanī Maḥmūd 'Abd al-'Āṭi in 1993. In his sìra the author gives evidence of his mastery of rhetorical techniques by his use of rhymed prose $\left.\left(s{ }^{\prime}\right)^{\prime}\right)$ at key points. For the most part, however, he employed a simple, matter-of-fact style, as in the hail story quoted above. Ibn Di'tham used the same technique of stylistic alternation when enlarging on religious concepts and arguments: usually he tried to keep his writing on these often complex issues as simple as possible in order to remain intelligible to the wider population as they gathered, for example, in market places or in mosques after the khuțba or Friday sermon. However, he occasionally shows off his religious education by alluding to passages of the Qur'an or by including sentences that are likely fully intelligible to experts only. Ibn Di'tham's purpose in the above passage was to explain why the Mutarrifiyya is bad, and why the imam is good. This point should be accessible and comprehensible to everyone. At the same time he strove to offer delicacies for experts.

Ibn Di'tham's biography of 'Abdallāh b. Hamza contains several stories of incidents in which rain plays a major role. They precede the story of the hailstorm, thus the trope of weather as a reward for obedience or punishment for resistance to the imam is already well-known to the listener/reader. That God was on the imam's side is suggested implicitly again and again, although neither the connection between God, rain, and the imam, nor the direct causality between obedience toward the imam and a subsequent reward in the form of rain, are ever made fully explicit. In

\footnotetext{
16 "Rising of Full Moons and Confluence of Rivers concerning the Biographies of the Men of the Zaydiyya.” Aḥmad b. Șāiḥ b. Abī l-Rijāl, Mațla‘ al-budūr wa-majma' al-buhūur fì tarājim rijāl al-Zaydiyya, ed. Hajr.

17 Ar. Sayf mașlūl 'alā l-Muțarrifiyya.

18 A possible fourth part may have been identified by Ansari. See Ansari and Schmidtke, "The Literary-Religious Tradition among 7th/13th Century Yemenī Zaydīs,” 168, fn 15.
} 
the imamic biographies there are many stories of how rain and prosperity follow in the footsteps of the imams. ${ }^{19}$

The incident of the hailstorm is said to have taken place in a mountainous region called al-Ahnūm. The village mentioned, al-Huraymāt, cannot be found on a modern map, but al-Ahnūm is a well-known area, perhaps best known for the mountain fortress Shahāra with its famous arched stone bridge connecting the two peaks and two parts of the settlement.

Around 1200 the extent and form of God's agency in the world was a hotly debated topic within the Yemeni Zaydiyya. The two main branches of Zaydism in Yemen, the Mukhtari ' $\mathrm{a}^{20}$ and the Mutarrifiyya, came down on different sides of this doctrinal debate. ${ }^{21}$ The conflict took on strong political dimensions, to which we will return below.

Before we comment on the story about the hailstorm, however, we need to set up its physical, political and cultural context. A brief outline of the relevant geography and political situation will be followed by an overview of the main theological positions at the time, including some examples. After this contextualisation, we shall visit the hail story one more time towards the end of the article, this time revealing even more details of its potential meaning in the formation of visions of community where orthodoxies and obedience are central.

\section{The Yemeni Highlands around 1200}

The geographical context of the hailstorm are the Yemeni highlands, a hilly plateau located at around 2000 metres above sea level running north-south between the areas of Șa'da and Dhamār, with the city of Sanaa between them. The western part of the plateau is a rugged landscape of deep relief that ends in an escarpment falling sharply down to the coastal plains. To the east, the plateau fades more gently into the desert called the Empty Quarter. On the plateau, rainfall is abundant in the south and west, while towards the north and east supplementary irrigation is necessary, usually taking the form of water runoff being led from adjacent grazing or barren lands onto agricultural terraces. The most important crops are sorghum, wheat and barley. The amount and timing of the rain is crucial since water in this type of agriculture is only stored as soil humidity. The highlands were inhabited by sedentary tribes who, for most of the time, were not under the control of any state but dominated by local tribal elites. The Zaydīs arrived in this area around 900. Several

19 In Ibn Di'tham's biography of 'Abdallāh b. Ḥamza e.g. 251; 299. The authors are currently working on this issue.

20 The Arabic name of the group leads back to a verb meaning "to invent, to produce, to bring into existence". See Lane, An Arabic-English Lexicon, 724c.

21 For an overview, see Schwarb, "Mu'tazilism in the Age of Averroes," 266-276. 
successive Zaydī imams (who were religious and political leaders) tried to create Zaydī Islamic states in the northern highlands, some managing to venture south and capture Sanaa. Most of the Zaydi imams, however, only held power over the tribal areas around Șa'da and Najrān and the areas between Șa'da and Sanaa. ${ }^{22}$

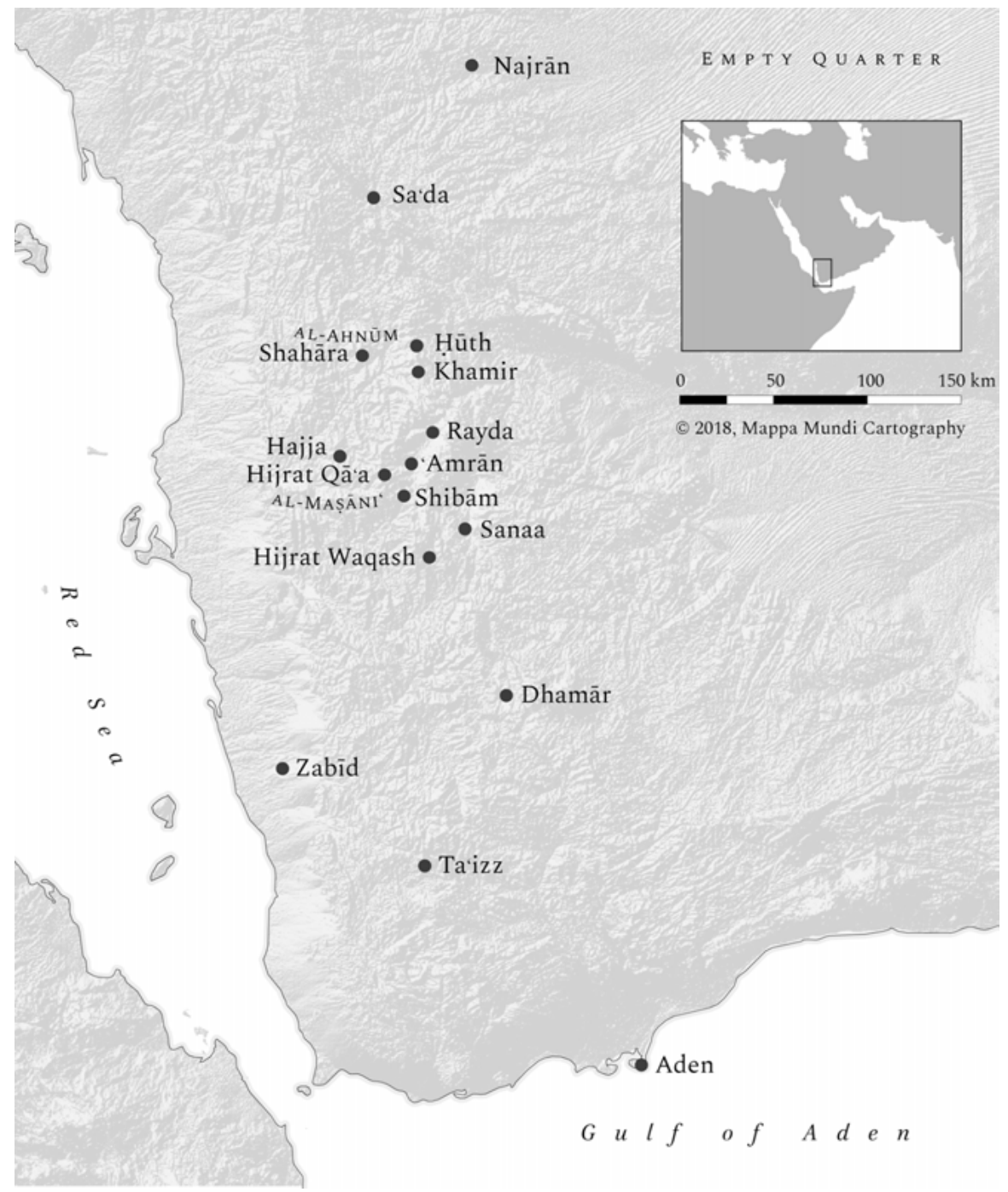

Fig. 1: The Yemeni Highlands

22 Studies about the Yemen comprise Dresch, Tribes, Government, and History in Yemen; Gochenour, "The Penetration of Zaydi Islam into Early Medieval Yemen;" Gochenour, “Towards a Sociology of the Islamisation of Yemen;" Zayd, Mu'tazilat al-Yaman; Heiss, "Tribale Selbstorganisation und Konfliktreglung;” Madelung, “Zaydiyya.” 
By 1100 a complicated denominational geography of Yemen had developed. Sunnī elites controlled the areas along the coastal plain in the west; Ismā'îlīs controlled the mountains south and west of Sanaa, and the Zaydiss were active in the tribal highlands north of Sanaa. The Sunnīs were nominally loyal to the Abbasids, while the Ismā îlīs had close ties to the Fatimids in Egypt. However, most of the northern part of the Ismā īli area was ruled by a local tribal dynasty centered on Sanaa, the Hātimids, who did not have a clear religious affiliation. This allowed some Zaydīs to operate inside nominally Ismā'îlī territory around Sanaa. The political-denominational borders were not as sharp as this textual map suggests and continued to shift over time. What such shifts meant to the local population is not clear. Certainly, it meant a change in to whom they paid their taxes and owed military service. However, it is unlikely that they changed their beliefs with each change of ruler, and perhaps not even their rituals (the different Islamic denominations have slight, but potentially visible ritual differences).

By c. 1200, most of the formerly Ismā'îlī areas were ruled by Sunnīs, as most of today's northern Yemen had been invaded by the Sunnī Ayyubids in 1174, and only some minor pockets of Ismā îlī orientation remained. When Sunnīs and Ismā îlīs refused to submit to the Zaydī imam, they were often defined as rebels (bughāt), a specific category of Islamic law of the state (fiqh al-siyar), and hence the Zaydi imam could initiate punitive campaigns. However, rebels could not easily be declared unbelievers (kuffār) since they were, after all, Muslims. Indeed, to call them rebels instead of unbelievers both made a pragmatic interaction possible and provided the imam with the option of employing punitive violence whenever he considered it advantageous. ${ }^{23}$ The declaration of the Mutarrifiyya as unbelievers was thus an unusually strong reaction, necessitating quite some production of theological polemics.

In the rest of this chapter, we shall concentrate on the Zaydi areas north and west of Sanaa and focus on sectarian dissent within Zaydīsm in this area, more specifically the tensions between the two branches of Zaydism at the time, called alMukhtari'a, who had the imam on their side, and al-Muțarrifiyya. Both claimed to be the true Zaydīs and Muslims.

Most of history writing by Zaydīs focused on the imam and his role as both a political and religious leader. The Zaydi imams called themselves "Commander of the faithful" and claimed the leadership of all Muslims. In practice, they had to compromise both in geographic scope and vis-à-vis the powerful tribal elites inside their own areas. Most of the sources we have from this period are the biographies of these imams, ${ }^{24}$ usually compiled shortly after their death by their secretaries. These

23 Kruse demonstrates the important difference between bughät and kuffär in Yemeni Zaydism, see Kruse, "Takfïr und Ǧihād bei den Zaiditen des Jemen."

24 List of biographies: 'Alī b. Muḥammad b. 'Ubayd Allāh al-'Abbāsī al-'Alawī, Sīrat al-Hādī ilā alḤaqq Yahyā b. al-Ḥusayn, ed. Zakkār; Abū l-Ghamr Musallam b. Muhammad b. Ja'far al-Laḥjī, The Sīra of Imām Aḥmad b. Yahyyā al-Nāṣir li-Dīn Allāh; From Musallam al-Lahjī’s Kitāb Akhbār al-Zaydiyya bi l-Yaman, ed. Madelung; al-Ḥusayn b. Aḥmad b. Ya'qūb al-Hamdānī, Sīrat al-Imām al- 
biographies, while largely modeled on the biography of the Prophet, also contain much detail about the careers of the imams concerned, the history of their times and of regents in peaceful or warlike contact with the imams. The biographies are usually arranged chronologically and incorporate different textual topoi and types of documents: descriptions of battles, stories of failure and success, administrative documents, theological and legal treatises, letters, and poetry.

In Zaydism, the imamate is not considered to be hereditary, but - at least in theory - only someone descending from the Prophet was allowed to claim the imamate. The Zaydī imamate lasted until 1962, having effectively turned into a hereditary kingdom under the Qāsimī (c. 1600-1850) and later the Hamīd al-Dīn (1911-1962) dynasties. The claim to the imamate was often disputed, resulting in frequent military conflicts between competing claimants. However, in the early phase of Zaydism in Yemen, between 900 and 1200, few imams were politically strong, and thus Zaydī scholars and supporters arguably became used to operate without an imam at a local level. ${ }^{25}$ As a result, the occasional imam pretender who claimed authority over the whole Zaydi community often met resistance from within the Zaydi community, or parts of it. This was certainly true in the case of Imam al-Manșūr 'Abdallāh b. Hamza around 1200. He ruled as imam from 1197 until his death in 1217 and controlled the tribal highlands down towards Sanaa which itself was held by the Ayyūbids. The Mutarrifiyya was a special challenge for him as they were an inner-Zaydi network or movement opposing his imamate and thus his right to collect canonical taxes and enforce government. Al-Manșūr's condemnation of the Muṭarrifiyya grew in intensity and culminated in the takfir ("excommunication") of the movement and in physical attacks. ${ }^{26}$

By 1200, the Zaydī community had also geographically split into two, roughly along a line running from Sanaa via Rayda to al-Ahnūm. East of this imaginary line, the imam was backed by the Mukhtari'a and held political power through local tribal and scholarly elites, while the Mutarrifiyya was dominant in the west, particularly in areas like al-Mașāni' and from today's 'Amrān south in a semi-circle round Sanaa on its west side through Thulā', Shibām and what is today Banī Mațar, south to Ânis. The imam tried to establish his authority also over the Muṭarrifiyya but met much resistance. The issue of collecting and redistributing taxes may have been a decisive factor in the enmity between the imam and the Muṭarrifîs. The Sunnī Ayyubids partly controlled the areas in which most of the Mutarrifiyya operated, along

Manșūr Bi-Llāh al-Qāsim b. 'Alī al-'Iyānī, ed. al-Ḥibshī; Mufarriḥ b. Aḥmad al-Raba'ī, Sĩrat alAmìrayn, ed. al-Sayyid and 'Abd al-'Āṭī; Sulaymān b. Yaḥyā al-Thaqafì, Sīrat al-Imām Ạ̣mad b. Sulaymān, ed. 'Abd al-'Āṭī; Abū Firās Ibn Di'tham, Al-Sìra al-Manșūriyya: Sīrat al-Imām 'Abdallāh b. Hamza, ed. 'Abd al-'Āṭì.

25 Heiss and Hovden, "Competing Visions of Community in Medieval Zaydī Yemen.”

26 Madelung, "al-Manșūr Bi'llāh.” 
with Sanaa, making it difficult for the imam to launch military campaigns into these regions to enforce his fellow Zaydī subjects' obedience. ${ }^{27}$

\section{Theology and Cosmology}

The theological and cosmological views of the Mutarrifîs were unique amongst contemporary Muslim denominations. Among the views they held, or at least were accused of holding, were particular theories regarding the causality of natural phenomena. Most of the sources we have were written by their adversaries, except for a few which will be looked at below. The Mutarrifiyya supposedly viewed God as the one who gave the original first push, the initial act of creation, but then left natural matters and bodies (ajsām) to react and interact with each other without further divine interference. Without going into too much detail regarding the highly complex theological debates between the Mutarrifiyya and the Mukhtari'a, we need to review some of these issues in order to understand the story about the hailstorm.

According to the author of the hail-story above, the Mutarrifis claimed that God created the world in one go or "strike" and brought into being four fundamental elements (ușūl), water, air, wind, and fire, which in various mixtures constitute all things (bodies, ajsām) around us. After God's first “strike”, these elements started reacting with each other and through those interactions continually developed and transformed (ihāala and istiḥāla) into new forms. According to the Muṭarrifîs, God does not intervene in the everyday creation of phenomena, which were called "accidents" ( $a^{\prime}$ râa $)$ in contemporary theological terminology. Rather, God created the basic substances (al-ușull) at the beginning of time and only gave the initial push. ${ }^{28}$ Rain, for example, is thus a form of water that simply happens to gather in the skies, forming clouds and falling down forming a certain incident or phenomenon. It is not created as a separate incident, accident, or phenomenon out of nothing (ikhtira $\bar{a}^{c}$ ), it simply changes its form or composition. By contrast, the name for the group opposing the Mutarrifiyya, the Mukhtari'a, is derived from the notion of ikhtira $\bar{c}^{\text {, }}$ creatio ex nihilo. In this theory, God is directly behind every phenomenon ( $a^{\prime} r \bar{a} d$ ) in the world. We should not, however, automatically assume that the Mutarrifiyya and the Mukhtari'a were clearly-defined, distinct groups that were internally theologically homogenous. In the contemporary literature, these group terms are used as charges of mistaken belief and thus represent an external, negative "la-

27 The best review of the historical events, according to the available sources, is given in Zayd, Tayyārāt, 144-198.

28 'Alī Muhammad Zayd claims that these four elements came from Greek philosophy but that earth was exchanged with wind in order to stay within the teachings of the first imam in Yemen, al-Hādī ilā al-Ḥaqq Yaḥyā b. al-Ḥusayn. It was certainly important for the Muṭarrifiyya to claim that they stayed within 'orthodoxy' and the tradition of al-Hādī. Zayd, Tayyārāt, 259. 
belling" or "branding" of the other. Particularly in the politically charged genre of biography written by authors on the imam's side, the use of the term "Mutarrifiyya" indicates strong condemnation. For the sake of convenience, however, modern scholars use these terms neutrally to denote the various parties.

As mentioned above, most of the information we have about the views of the Muțarrifiyya comes from their adversaries. The only surviving theological treatise by a Muṭarrifī scholar is called al-Burhān al-Rā'iq al-Mukhalliṣ min warț al-maḍā'iq ("The Shining Clarified Proof of Difficulties in Narrow Places") and was written by Sulaymān b. Muḥammad b. Aḥmad al-Muhallī. ${ }^{29}$ The Yemeni historian 'Alī Muhammad Zayd assumes that al-Muhallī was a contemporary of the Mukhtari'î (and strongly anti-Muṭarrifī) court scholar and chief judge al-Qāọī Ja'far b. 'Abd al-Salām (d. 1177) because al-Muhallī refers to the Mukhtari'a as the Ja'fariyya. At the same time, 'Alī Muhammad Zayd argues that Muhallī likely wrote the Burhān not long after al-Qāọi Ja'far b. 'Abd al-Salām's death, because the treatise does not mention Imam 'Abdallāh b. Hamza who was the next strong opponent of the Muṭarrifiyya and who became active in the 1190s. ${ }^{30}$ Most of the Burhān unfortunately remains unedited and consequently little studied. In this article, we shall only have a brief look into some of its riches to get a feeling for the style and construction of the arguments as found in the sections edited by 'Abd al- ${ }^{-}{ }^{t} \overline{1}^{31}$ and through a summary given by 'Alī Muhammad Zayd.

\subsection{On the Nature of Rain}

One section in the Burhān is called Bāb al-qawl fì l-ușūl wa-l-jawāhir ("Chapter on the Theory of Fundamental Elements and Atoms"). ${ }^{32}$ The form, style, and sequence of argumentation show that the author wants to portray himself as an orthodox Zaydì in line with well-known earlier Zaydī authorities. The basic argument of this section is to prove, first of all, the existence and importance of the fundamental elements, secondly, that all other things, such as animals, trees, and clouds, come from these, and thirdly how some things have different compositions of these original fundamental elements. The existence of the elements is proven with reference to the Qur'an and to authoritative texts written by famous Zaydīs. Al-Muhallī starts by discussing the centrality of water as a basic substance that forms an important part of other things. He explicitly mentions that rain comes from clouds. He also refers to the many passages in the Qur'an where water is given a prominent role, such as

29 Madelung, “A Muțarrifĩ Manuscript.” Zayd has made a rough edition/summary of parts of the work with some analytical comments: Zayd, Tayyārāt, 201-308.

30 Zayd, Tayyārāt, 202.

31 'Abd al-Ghanī Maḥmūd 'Abd al-'Āṭ̂, al-Ṣirā' al-fikrī fì l-Yaman bayna l-Zaydiyya wa-l-Muṭarrifiyya, 51-90.

32 al-'Āṭî, al-Ṣirā' al-fikrī, 53-56. 
"We created from water everything living" (Anbiyā' 30) and "His throne was situated over water" (Hud 7). He goes on to quote passages by the early Zaydi Medinan scholar/imam al-Qāsim b. Ibrāhīm al-Rassī (d. 860) , $^{33}$, the grandfather of the first imam in Yemen, about how pastures and trees are absolutely dependent on rain and that this can also be easily seen in practice. The author thus also includes "scientific observations" in addition to references to authoritative texts or persons.

Al-Muhallī quotes al-Hādī's statement that the fundamental element in earth (ținn) is indeed water, as well as al-Hādī's reply to a question by his son al-Murtaḍā, in which he explains that everything is created from the fundamental elements (ușūl) water, air, wind, and fire..$^{34}$ In creation, water can react with heat (fire), turn into steam and ascend into the air. This is then connected with the Qur'anic verse Fușṣilāt $11 .^{35}$ Al-Muhallì ends by stating that the two sons of al-Hādì, al-Murtaḍa and al-Nāșir, also "mentioned [...] these issues". The meaning of some of the Qur'anic verses he uses is ambiguous and therefore open to alternative interpretations. However, instead of potentially laying his argument open to criticism by referring to the inherent ambiguity in these difficult Qur'anic verses, the author simply uses a style of argumentation where as many Qur'anic verses are referred to as possible, aiming for a cumulative effect. By invoking sources like the Qur'anic and early Zaydī authorities first, then moving on to the later Zaydī authorities, such as al-Hādì and his two sons, a hierarchy of authority becomes apparent. On the whole, the argument appears plausible, at least its foundation in "orthodoxy", namely that the four elements are well attested in Zaydism. Indeed proving the orthodoxy of his claims, rather than arriving at new knowledge from the textual sources themselves, seems al-Muhalli’s main objective at this point.

The treatise's next section is called Bāb al-qawl fi l-ihâla ("Chapter on the Theory of Transformation”). Al-Muhalli states that God created the world changing and transforming (yahilu wa-yastahilu). Furthermore, everything was created with a meaning or purpose, and this is to be either useful for man or a danger; and this cannot be changed (jabr). This is simply how the world is created; fire burns, water quenches, food satisfies, blankets warm, medicines cure, etc., all with God's force (jabr), and with almost mechanical regularity. Bodies keep reacting with other bodies, transforming them, and leading to new interactions and forms. This is getting close to a picture of a deistic or even "godless" nature ruled only by natural laws, but al-Muhalli continues by stating that God is the ultimate cause. He actively takes a position defending himself from accusations of taking the "natural world" out of the divine reach.

33 Madelung, “al-Rassī, al-Ḳāsim b. Ibrāhīm b. Ismā'īl Ibrāhīm b. al-Ḥasan b. al-Ḥasan b. 'Alī b. Abī Ṭālib;” Madelung, "Der Imam al-Qāsim ibn Ibrāhīm und die Glaubenslehre der Zaiditen.”

34 al-'Āṭi, al-Ṣirā' al-fikrī, 55.

35 "And He applied His design to the skies, which were [yet but] smoke; and He said to them and to the earth, 'Come [into being], both of you, willingly or unwillingly!' to which both responded, 'We do come in obedience'.” (translation Asad, slightly changed) 
As for what they say, that if we assume that the world is constantly transforming, then this must be outside of God's active interference (tadbir), then how can this be outside God's active interference when God's interference in the world is how this world is, be it by intention (qașd) or by its natural disposition (fitra). ${ }^{36}$

As many modern scholars have established, at this time too great a reliance on philosophy in Islamic theology was considered dangerously close to heresy. In order to be accepted as "Islamic", authors had to operate within a theological/cosmological framework in which God was central, and to couch their arguments in theological terms.

Accordingly, when al-Muhallī describes something similar to natural laws that God has created and set in motion, he chooses his exact wording and terminology carefully to avoid any accusation of following the tabīiyya, ${ }^{37}$ meaning something like "those who believe in (godless) nature". Al-Muhallī goes far in setting up a system without God, in the sense that God is only the prime mover, but he carefully and explicitly states that God is ultimately behind these patterns in the world, and that whether or not God actively intends them, they are a result of His creation. As God originally created the world, the world is God's and therefore not godless. The transformations of things happen according to God's original will. How this theory fits with God's ability to occasionally intervene to punish the faithless and reward the faithful is not touched upon in this chapter but dealt with elsewhere, as are the questions of how such a theory relates to divine justice and various degrees of free will. It is not our intention here to describe the teachings of the Burhān in general; important for us in the context of this chapter is one further passage discussing the element of water. Interestingly, the examples and metaphors used are not completely theological but do draw on examples of common sense from engineering and farming. The following is a summary of a section of the Burhān given by 'Ali Muhammad Zayd. It refutes the theory of $i k h t i r \bar{a}^{c}$, of creation out of nothing. Here, al-Muhallì gives several examples related to water:

A water mill rotates faster if the amount of water or the inclination of the millrace increases, and the mill will rotate more slowly if the water flow decreases and the inclination of the millrace becomes horizontal. This is evidence that the practical determinant of the operation can be conceptualised with a theory that is built on bodies (ajsām), which invalidates the theory of ihkhtira $\bar{a}^{c}$ of phenomena. If it were true that phenomena are created ex nihilo then there would be no meaning [as a factor of explanation] of more or less water, or a steeper or more horizontal angle of the millrace.

$\overline{36}$ al-'Ạțī, al-Ṣirā' al-fikrī, 61 . The term fitra is important as it refers to a universe where God is still in charge, as distinct from tabc, nature. The same regards the use of the term jabr, a couple of sentences above. This very issue is still discussed today, see al-Wazīr, Zayd b. 'Alī, Badr al-Dīn al-Ḥūthi, and Muhammad Sālim, "Ḥiwār 'an al-Muțarrifiyya." Al-fikr wa-l-ma'sāt, Kitāb al-Maṣār, vol. 2, for example on page 224.

37 See Zayd, Tayyārāt, 178, 304. 


\begin{abstract}
It can also be observed (yustashhadu) in a fountain (shädharwān) where the height and the power of the water jet, and its amount, are dependent on its operation and its construction. This is further evidence (yadillu 'alā) for the invalidity of $i k h t i r \bar{a}$ ' al-a'rāẹ.

It can also be observed in the power of flowing water (sayl) according to the amount and the steepness of the canal or its horizontality. As it can also be observed in a stream that a farmer leads to his land, diverting it, in full control, to where he wants. If the one who takes the water does this according to the physical layout (bunya) of the river, then this is what the Mutarrifiyya claims. And if it [the water] only floats according to what God creates at any moment, then this is not true, because even a child can prevent it from flowing, and how could it be possible to stop something that God has created. ${ }^{38}$
\end{abstract}

These thought-experiments are particularly interesting as they do not build on revealed textual evidence but on physical occurrences that can be observed and understood by both experts and laymen alike. However, the terms, concepts and theories - such as bodies, phenomena, or transformation - derive from theological discourse and have theological-political connotations. The exact meanings of these terms would necessitate an analysis of the discourse(s) in a much broader perspective, particularly the established discourse of $a^{\prime} r \bar{a} \underline{d}$ and ajsām in Mu'tazilì theology and in theological discourses of the wider Islamicate world. One would also need to take into account the exact developments of these theories taking place in Yemen and elsewhere shortly before the Burhān was written, including the level of familiarity of the scholars of the Zaydiyya with other disciplines such as philosophy, science and medicine. However, what is important for this chapter is how the seemingly minute and technical details of theology take on legal and political relevance, as we shall see below.

Describing a system of "natural laws" - even though al-Muhallī seeks to wrap it in a language of orthodox theology - does leave God with less power, or should we say, with less interest in the world compared to the theory of ikhtira $\bar{a}^{c}$. That is a problem for those who want to interpret incidents or natural phenomena as divine punishments or rewards, or as signs of apocalypse. In the context of al-Muhalli’s theory, it is easy to claim that a certain rainstorm was not the act of God, but simply an ordinary phenomenon that has "its own" cause and was therefore not related to human misbehaviour or lack of obedience. It does diminish God's ongoing, active role in his creation - one might say that the world becomes partly "secular", or at least opens for that possibility. No wonder that this was an irritating theory for theocratic leaders, and not only because it was hard to argue against.

38 Translated from Zayd, Tayyārāt, 261-262. It is not clear how strictly Zayd read the text, or if he at times inserted his own words. 


\subsection{The Views of al-Laḥji}

We should be cautious in extending the theological reasoning found in al-Muhallī's Burhān to all Muțarrifīs. Musallam al-Lahjij’s (d. ca. 1150) works, probably written a decade or two before Burhān, are much less "expert-theological” in style and mainly recount the pious acts of individual Mutarrifis. Al-Lahjị’s take on the connection between good deeds and their reward (or bad deeds and their punishment) in the form of natural phenomena is particularly interesting, as he leaves the exact causal relations open. An example of this can be found in his biography of Ismā'il al-Muzayyin, a member of the Muțarrifí community a century or so before al-Lahjī. We are told that Ismā'îl performed a pious act by giving part of his harvest to other Mutarrifis out of his love for them. Suddenly a heavy rainstorm destroys the neighbouring fields (supposedly of non-Muțarrifis), while the field of Ismā'īl is left intact. ${ }^{39}$ There $^{-}$ is no direct mention of God interfering or of a miracle, but it is clear from the narrative that there is some sort of "unusual", not natural connection. We can therefore safely say that the Muțarrifi view on God's involvement in natural phenomena was not as monolithic as the opponents of the Mutarrifiyya tended to describe it, presumably in order to produce a sharp opposition or dichotomy.

In the following paragraphs from the biography of his teacher, al-Ḍāmī, al-Laḥji describes his own childhood in Shazab (today's al-Sūda or al-Sawda, north-west of 'Amrān), in which he represents himself as a "thinker" already during childhood and youth:

I used to try to bring something into being (ijād), something touchable that could remain at my disposal, but I did not find anything like it. Indeed, I once arrived at a cistern (birka) in which there had been water which had later come to an end, and in it remained wet clay. I took a piece of it, shaped it into a different form, and said to myself: 'I brought (awjadtu) this into being!' Then I realised something in my mind saying: 'No! Rather the existence of clay (wujūd al-țin) was there before you, it was gathered up here by the flood-water (sayl) and not from pressure [your shaping of it].'

Then I aimed at the air, high up, trying to capture some of it. However, I was not able to do so. Then the voice said inside me: 'Even if you had managed to capture some of it, you would not have brought it into being, because bringing into being ( $(\bar{j} j \bar{a} d)$ is impossible (lā min shay'). ${ }^{, 40}$

Then I jumped up into the air, [thinking that] maybe I could remain in it; however, I was not able to do so. I returned to myself and I realised that it is not possible for me to bring into being bodies (ajsām) and likewise, nor to exceed the habit of man (khurūj 'alā 'ādat al-bashar) I was thus convinced that I was created $(m a s ̦ n \bar{u})$ and that I have a creator (șāni ') who is able to do what I am unable to, out of his grace ${ }^{41}$, and that he is different from me. I found in myself

39 See the story about Ismā'îl al-Muzayyin translated on pages 398-399 in Heiss and Hovden, “Competing Visions of Community in Medieval Zaydī Yemen.” Zayd, Tayyārāt, 202; al-'Āṭī, alȘirā' al-fikrī, 51.

40 al-ìjād lā min shay'. Shay" can here possibly both mean "thing" in the common sense, as well as the common colloquial usage "nothing".

41 This word is unclear in the manuscript. 
knowledge of what I was able to do, which is the transformation of the clay from one form to another, and that the clay [itself] is something different [from its form], and that I am able of only one thing: movement ${ }^{42}$ (haraka).

This all happened when [I was so young that] I had no idea about the term for things like this, but I imagined it as something distinct from earth and air and myself. I did not know at the time that it is called 'phenomenon' ('arad). These and similar issues were present in my thinking. $^{43}$

In this story we are given a fascinating insight into Lahjị's descriptions of his own childhood thinking. Before and after the passage above, he describes some of his curriculum, habits, and interests. By suggesting that these theological theories could be developed even by a child, and without knowledge of the correct terminology, he almost seems to mock the experts' theology and their categories, perhaps also rather specifically the theory that the world is divided into bodies (ajsām) and phenomena ( $a^{\prime} r \bar{a} d \underline{\text { ) }}$. One possible way of reading al-Lahjīi is that humans are able to use their senses and their reason, and the theological concept of "phenomena" ('arad, a'râd) is perhaps superfluous. How all of this might be combined with the texts of revelation he leaves completely open.

In this work, al-Lahjī's approach to theology and Islamic law is - as in the example above - largely anecdotal and implicit, and we should therefore be careful to ascribe to him explicit opinions or theoretical positions he might not have held. However, the passage quoted illustrates that an interest in theological issues does not necessarily have to be confined to specialist discourse. It can also start from the basic experiences of being human, and in such a way be accessible also to ordinary villagers and farmers, at least on some level. In fact, this seems to be al-Lahjī's main point. ${ }^{44}$

42 Or, perhaps "action".

43 Abū l-Ghamr Musallam b. Muḥammad b. Ja far al-Laḥjī, Akhbār al-Zaydiyya min ahl al-bayt 'alayhim al-salām wa-shī'atihim bi-l-Yaman ("Manuscript, Jāmi'at al-Imām Muhammad b. Sa'ūd al-Islāmiyya, MS no. 2449"), 179. Al-Lahịi uses a low register of language, to such an extent that these passages might not be classified as "theology" by some. In the passage cited above al-Lahji obviously avoids the terms used in the Qur'an, where in sūrat Șād (38:71-76) God says to the angels: "Behold, I am about to create a human being out of clay". The Qur'anic passage, obviously the model for al-Lahjī, uses khalaqa and sawwiya, whereas our author says awjada, șawwara, and șana'a. Ajsām is mentioned for the first time with a negative connotation, as is 'arad, which only appears at the end of the story.

44 Jan Thiele presents an in-depth analysis of the work of al-Ḥasan al-Rașạaṣ (d. 1188), one of the local adversaries of the Muțarrifiyya, whose treatises on Islamic theology and natural philosophy exemplify a high level of scholarship at the time. Al-Lahjī's terminology, even if presented as an easily accessible narrative, should also be read carefully against the discourse that al-Raș̣̦āṣ engages in and elaborates upon. Some of the terms al-Lahjī uses above fit with al-Raș̣āș’ list of subcategories of accidents. See Thiele, Theologie in der jemenitischen Zaydiyya, 73. 


\section{The fatwā of Imam al-Manșūr 'Abdallāh b. Ḥamza}

Around the year 1200 the Mukhtari'a could rely on very advanced Mu'tazili rationalist theology imported from the Zaydī communities in what is today northern Iran. ${ }^{45}$ Nevertheless, it seems that many local Yemenis preferred the natural causation theory of the Muṭarrifiyya, or were in any case content not to side with Imam al-Manșūr 'Abdallāh b. Ḥamza and his court scholars. Reasons could also have been partly political or economical, such as reluctance to pay the canonical taxes to the imam. The issue of natural versus divine causality of phenomena became a political marker of difference, indicating one's allegiance. The causes of rainfall became one of the very foci of disagreement. The tensions between Imām 'Abdallāh b. Ḥamza and the Mutarrifiyya grew over time and the rhetoric became increasingly strident, as 'Ali Muhammad Zayd has shown. ${ }^{46}$ It seems clear that at this time, the Muṭarifiyya was (at least accused of) claiming that rain is not created or sent by God. Proof of this accusation is the fatwā by Imam 'Abdallāh b. Hamza, issued as a response to questions coming from Amīr Nūr al-Dīn al-Ḥasan b. Yaḥyā b. 'Abdallāh b. al-Hādī ilā al-Ḥaqq:

Related to that: About someone who rented out his land (ista'jara ${ }^{47}$ ) to a Muțarrifi for the [period of the travelling to Mecca for] hajj, and set aside (akhraja) for him some of the obligatory taxes (huqūq), this being before the time of the [present, righteous] imam, and believing that his [the Muțarrifi's] doctrines were right. Is it necessary to pay a fine (gharāma) for this or is it not necessary? ${ }^{48}$

Amīr Nūr al-Dīn is asking to what extent the taxes paid (huqūq Allāh, such as zakāt) are valid taxes or zakāt when given to a Mutarrifì if the payer trusts the latter to spend them in the right way. The answer discusses issues related to the lease and the fine, but here we shall focus on the first part of the answer, which deals with how to recognise a Mutarrifi, in fact: how to define the heresy.

The answer to that: The heresy ( $k u f r$ ) of a Muțarrifî is not defined by the term [Muțarrifi], just as a Mukhtari'i is not [always] right (najät) by that name, the legal effect [of apostasy] only comes from the doctrines (i'tiqād) that they hold. If he [the Muțarrifi] believes what is typical for their school, denying that God, the Exalted, tests [man], and likewise His habit of granting mercy to whomever he wants, the sending of rain (inzāl al-ghayth) after despair, His creation

45 For an excellent overview over the actors, process and context of this "transfer", see Schwarb, "Mu'tazilism in the Age of Averroes;" Ansari and Schmidtke, "The Literary-Religious Tradition among 7th/13th Century Yemenī Zaydīs;" Ansari and Schmidtke, "The Cultural Transfer of Zaydī and non-Zaydī Religious Literature from Northern Iran to Yemen.”

46 Zayd, Tayyārāt, 156-192.

47 From the verb it is not entirely clear who rented the land to whom, but the second time the verb is used the context suggests that the Mutarrifi tenant is not considered worthy to take and pass on the $z a k \bar{a} t$ for the right purpose or right authority.

48 Ibrāhīm b. al-Qāsim b. al-Mu'ayyad, Ṭabaqāt al-Zaydiyya al-kubrā, ed. al-Wajīh, vol. 2, 223-224. 
for death and life in large and small, elevation of some servants above others in classes (dara$j \bar{a} t$ )[Q 43:32], preferring some of the Prophets above others, and similar to this, then this is apostasy (ridda) according to the Ahl al-bayt, peace be upon them, and according to the 'ulamā' of the Umma. Thus the apostate cannot be leased [land] (al-murtadd lā tașihhu ijäratuhu), and [one can] not submit the canonical taxes to him (taslìm al-ḥuqūq ilayhi), according to consensus $(i j m \bar{a})[\ldots .$.$] .$

Here imam 'Abdallāh b. Ḥamza produces a neat "check-list” of a Muṭarrifî’s heretical beliefs. In general, its criteria do fit with the contents of the Burhān al-rā'iq as analyzed by 'Ali Muhammad Zayd. ${ }^{49}$ Several of the points concern God's active interference in the world. There is no room here to go into all of the items on the list, and we shall focus on the accusation that the Mutarrifiyya does not believe that God sends rain, and further, that this belief is seen as a heretical deviation from orthodoxy.

The fatwō's language is fairly straightforward. There is no theological reasoning, only a brief statement of the imam's opinion. He claims that his view is grounded in the school of the Ahl al-bayt (descendants of the Prophet) ${ }^{50}$ and represents the consensus of all scholars of the Islamic community. Although these two sources of validity do not prove the authoritativeness of his statement, he presents them as sufficient. Other treatises by the imam contain more elaborate arguments against the Muțarrifiyya, but in this fatwa $\bar{a}$, he confines himself to simply stating that the view that God does not send rain is heretical.

There was obviously much discussion of such issues in the Zaydī community at this time, as well as about the use of force exercised by the imam in defining orthodoxy. The construction of a clear line of theological demarcation between "us" and "them" was used to legitimate the use of military power and violence against the population in the geographical areas where the Mutarrifiyya was relatively strong. We do not know the exact timing of this fatwa , but it was one of numerous legal devices justifying the confiscation of property, killing of men, and taking of slaves amongst Mutarrifis. ${ }^{51}$ After establishing the theological and political context of Imam 'Abdallāh b. Hamza's activities, we can finally again turn to our central case study, the story of the hailstorm found in his biography. We are now better equipped for understanding the richness and the finer points of its rhetoric.

49 For example about the topic “equality in sustenance”, see Zayd, Tayyārāt, 92-94.

50 This is a common way of defining Zaydism, as apposed to Sunnism.

51 As for dār al-fisq as a third category between dār al-Islām and dār al-harb, see the fatwā in Ibrāhīm b. al-Qāsim b. al-Mu'ayyad, Țabaqāt al-Zaydiyya al-kubrā, ed. al-Wajīh, vol. 2, 64-67. Here the imam legitimates confiscating property of Mutarrifīs. 


\section{The Story of the Hailstorm in the Biography of Imam 'Abdallāh b. Ḥamza}

Ibn Di'tham, the imam's chief secretary, begins his story with a short summary of the beliefs of the Mutarrifîs.

The Mutarrifiyya, as far as we know about their creed, claim that anyone who wants to be a prophet can be so, the only exception being his incapacity ('ajz) ${ }^{52}$. Thus they exceed the unbelief (kufr) of the Banū Ḥanifa and others of the unbelievers (kuffär).

The disbelief of the Muțarrifís is compared to the kufr of the Banū Hanīfa. With the use of this example, Ibn Di'tham follows the imam who in his work al-Durra alyatìma fi tabyīn ahkām al-saby wa-l-ghanima ${ }^{53}$ introduced the Banū Hanīfa as an example of kufr (disbelief), and also contrasted them to the greater kufr of the Mutarrifis. ${ }^{54}$ The latter were to be judged even worse than the early enemies of the Prophet. There is a certain possibility that in his role as secretary Ibn Di'tham himself formulated the edicts and even, at least partly, wrote al-Durra al-yatima.

The Banū Hanīfa were one of the first tribes to renounce Islam, supporting their own prophet Musaylima..$^{55}$ They and their "false" prophet were frequently used as an example of unbelief. Their military suppression and its theological and political legitimation was used to support the opinion that it was legal to wage war against the Muṭarrifiyya and to kill them [hukm al-sayf], take captives, and confiscate their property.

The claim that anyone could be a prophet sounds far-fetched and is based on a probably deliberate blurring of the concepts of "prophet" and "imam". The idea that anyone, regardless of his background, could be an imam as long as he was qualified, certainly circulated and was heavily discussed at that time. Nashwān b. Sa'īd al-Himyarī (d. 1178 CE) was advocating this view shortly before the biography's composition. ${ }^{56}$ Opinions like his were an obvious threat to the imam's (and the Ahl al-bayt's) exclusive claim to political/religious power. However, most scholars consider that the Mutarrifiyya did indeed follow the doctrine that imams

52 That is, if he is not fit intellectually or otherwise.

53 "The Unmatched Pearl Concerning the Explanation of the Judgments on Taking Prisoners and Booty” edited in al-'Āṭī, al-Ṣirā' al-fikrī, 206-253.

54 The same use of Banū Ḥaniffa is made by Ḥumayd b. Aḥmad al-Muhallī (d. 1254) in his collection of imams' biographies called al-Hadā'iq al-wardiyya or "The Gardens of Roses". The last biography is the one of Imam al-Manșūr 'Abdallāh b. Hamza, where he makes the comparison between the Muțarrifiyya and the Banū Hanīfa with the same function. The relation between Ibn Di'tham's and al-Muhallī’s biographies of imam al-Manșūr has not yet been analysed.

55 His original name was Maslama; the name usually is given as a diminutive in derogatory use; often as a kind of nickname al-kadhdhāb is added, "the liar".

56 Nashwān's views on this is given in his work called al-Hūr al-iin. For a review of Nashwān's views, see Zayd, Tayyārāt, 111-115. 
had to come from the Ahl al-bayt, or at least did not openly contradict this doctrine..$^{57}$

After laying the general groundwork by raising the question of the imamate and reminding his readers of the Muṭarrifiyya's comparison with Banū Hanīfa, Ibn Di'tham sets the stage for the specific story's interpretation: that the Mutarrifiyya is the very opposite of the imam and of true belief. He starts the following part with "source criticism" of the traditional style by giving the personal names of those who told the story or those who could confirm it, among them an influential cousin of the imam.

In the same vein God the Exalted hit them [the Mutarrifiyya] with hail (barad) ${ }^{58}$, as is told by Marzūq b. Yahyā al-Jawrī ${ }^{59}$ and Yaḥyā and Qāsim, the two sons of Muhammad Fațịh ${ }^{60}$. Their account was confirmed by the Amīr Șafiy al-Dīn Muḥammad b. Ibrāhīm ${ }^{61}$, who was told this story by reliable persons who said:

'When the judgement of the sword [hukm al-sayf, declaration of takfir] had been passed on the Muțarrifiyya by the imam, peace be upon him, Rāshid b. Muhammad al-Ṣaqrī al-Janbīin ${ }^{62}$ refused to acknowledge it. In those days, he stayed in the region of al-Ahnūm where his influence was already established in its plains and mountains. He had propagated the madhhab of the Muțarrifiyya there and most of the inhabitants sympathised with it (māla ilayhi).'

Imam 'Abdallāh b. Hamza wrote a letter declaring the Muṭarrifiyya to be murtaddūn (from ridda, apostate) and kuffär (unbelievers). It must be this declaration that is referred to as "The Judgement of the Sword" here, with the consequence that anyone who upheld Muṭarrifĩ doctrines could be killed, his women and children enslaved, and his properties confiscated. When the story of the hailstorm was written down, the violent implications of this judgment (hukm) were already being carried out, making it likely that its wording was well known. ${ }^{63}$ Al-Ṣaqrī was one of the

57 Zayd, Tayyārāt, 94-95.

58 The word b-r-d can be read and interpreted in different ways: as bard, meaning "coldness, chill” (Lane, An Arabic-English Lexicon, 184b) or as barad, "hail, frozen rain” or barid, "possessing coldness or coolness" (Lane, An Arabic-English Lexicon, 184b); for barid Lane cites as example sahāba barida: "a cloud containing hail and cold." It seems that what is intended here is coldness, hail, storm, and icy rain at the same time. Lane, An Arabic-English Lexicon, 184c).

59 Al-Jawrī in the text, in the index al-Hawrī, which is palaeographically very similar.

60 In writing, Fațịh or diminutive Futayh are the same, an ambiguity.

61 The ibn 'amm (father's brother) of the imam, and one of his important generals, here obviously intended as a very trustworthy source.

62 A well-known leading Mutarrifi, mentioned three times in the biography; the vocalisation is not certain.

63 'Alī Muhammad Zayd claims that the first accounts of violence can be dated to 1206/1207. Zayd, Tayyārāt, 184. In the sirra itself, there is also a long treatise quoted, shortly after the hail story, where the imam invokes takfïr. Ibn Di'tham, Al-Sīra al-Manșūriyya: Sīrat al-Imām 'Abdallāh b. Hamza, ed. 'Abd al-'Āṭi, vol. 2, 863-883 (large parts in rhyme). At the end of the letter with the long poem, Ibn Di'tham states that it had a strong effect on people and that people from the western areas, such as al-Aḥūm and parts of Hajja turned away from the Muṭarrifiyya, where they previously used to pay 
Mutarrifi scholars/politicians who were still active at that time in the lands of al-Ahnūm, the mountains around Shahāra west of Khamir and Hūth. Ibn Di'tham refers to the Mutarrifiyya as a madhhab ${ }^{64}$ and acknowledges that this "way of believing" seems to be well-accepted among the population in that region.

Here a series of questions arises: Can we take this last piece of information as historical fact, or is it a part of the tendentious narrative and thus to be seen as a "literary" truth? The problem is that we do not have many sources from this time which we could use to "triangulate" and judge the content. Was the area of al-Ahnūm really Mutarrifî? And what would this mean? Does it mean that the doctrines of the Mutarrifiyya were well-known there, or simply that the population there welcomed the occasional Mutarrifi missionary? Did it mean that the population did not wish to pay taxes to 'Abdallāh b. Hamza and therefore rather "held" Muṭarrifin doctrines (who possibly demanded/offered to take lower taxes)? Or were the al-Ahnūm simply on the fringe of 'Abdallāh b. Ḥamza's area of operation and control anyway? Is this location in the story representative of the frontier lands that had to be converted? These questions cannot be answered by an interpretation of this story alone, but they should be kept in mind. Now the story takes a theological turn:

He [al-Ṣaqrī] was the shaykh of the ahl al-qafakha ['the people of the strike'] ${ }^{65}$, who maintain that God created the world in one strike [qafakha] and made some parts of it as a causation for [a continuous transformation into] other parts (wa-ja'ala ba'dahu yahilu ba'dan), and that God has no longer any direct role in his creation (wa-lam yabqa lahu tadbir fi khalqihi), so for him [God] no activity ${ }^{66}$ is left in his creation (wa-lā nazar fi bari'atihi) ${ }^{67}$.

the canonical taxes to them. Ibn Di'tham, Al-Sïra al-Manșūriyya: Sĩrat al-Imām 'Abdallāh b. Hamza, ed. 'Abd al-'Ạṭī, 2:889.

64 A madhhab is just "a way by which one goes or goes away", and also "a way, course, mode or manner, of acting or conduct" or "a way of believing, or opining, thinking or judging”, "a belief, a creed, a persuasion" (Lane, An Arabic-English Lexicon, 983b); in our case the word is used as something similar to itiqa $\bar{d}$ or established school of thought.

65 In the first instance, the editor has qahfa, in the second qafkha. The intention clearly is the use of the same word in both instances. Qahfa (or qihfa ?) would be "intense rain", cf. Nashwān alḤimyarī, Shams al-'ulūm, 5382-5385, but fits not as well as qafakha from q-f-kh "he struck him", v. Lane, An Arabic-English Lexicon, 2549c, where Lane mentions qafakha as "used by the people of El-Yemen in the sense of șaqa' $a$ " with the meaning "he struck a person's head with a staff". Șaqa' $a$ is (Lane, An Arabic-English Lexicon, 1706 a/b): "He struck him, or beat him." What seems to be intended is a presumably devaluating expression for the Muțarrifis who allegedly believe that God created the world "at one blow or strike" (qafkha) or "in one sweep", and that subsequently one thing influenced and changed the other without God interfering with it. Consequently the author calls the Muțarrifĩs ahl al-qafkha. Nashwān b. Sa'īd al-Ḥimyarī, Shams al-'ulūm wa-dawā' kalām al-'Arab min al-kulūm. Lane, An Arabic-English Lexicon, 2549c.

66 Could also be translated as "interest", “control”, "inspection”, meaning the role as an active overseer.

67 Wa-lam yabqa lahu tadbïr fi khalqihi wa-lā nazar fi bari'atihi: from a rhetorical point of view this is a parallelism where both parts of the sentence give practically the same sense - a nice example of the author's delicacies for the specialists. 
The theology and cosmology is here explained in simple words which end, however, with a succinct rhetorical manoeuvre. The arguments are formulated in a way that anyone with a minimum of theological background can understand. However, one can only be fascinated by the implications of this theological theory of natural causation. God only created the world in one go, and after that, the natural elements act and react with each other. This could mean that God does not anymore interfere in the world after the first act of creation. What are the implications of this for the imam's theocratic status? Does God actually support the imam, can such support be seen, does it exist? With arguments of that kind, the Mutarrifis could indirectly invalidate the imam's transcendental legitimation.

Again, one must be cautious about whether or not the Mutarrifiyya actually held these doctrines. If they did, it is highly likely that their leading scholars had developed far more sophisticated versions of this theory at a much higher level of abstraction, with built-in mechanisms to ensure compatibility with other theories. Contemporary theological experts employed complex theoretical devices to avoid extreme positions claiming absolute predestination or, on the other hand, complete free will. What is of interest in our context, however, is that Ibn Di'tham clearly wants to tell the story in a manner that renders it easily comprehensible to any intended listener or reader. He returns to the description of the situation:

He [al-Ṣaqrī] called for a meeting for everyone at a place called al-Huraymāt of the land of Banū 'Abd al-'Azīz in the region of al-Ahnūm. He described to them what had happened to his fellow Muțarrifis regarding punishment (nakāl), killing and confiscation of properties (ibāhat $a l-a m w a \bar{a} l)^{68} \mathrm{He}$ called for patience ${ }^{69}$ and perseverance in favour of their madhhab, the defense of their religion $[\mathrm{din}]$ and the keeping of their creed ${ }^{70}$ He aroused their feelings for fighting the imam, peace be on him, and they [the local people] responded positively.

This is an appropriate description of a political meeting. A man central to the activities of the Mutarrifiyya sums up the suffering of his companions and exposes the unrighteousness of their opponents. He calls for support and loyalty. But again, what is the historic value of this information, if any? Is this a first-order observation? The author gives no indication that he was present himself. He makes us believe that the meeting and the speech given there really happened by naming witnesses, as if citing a hadith of the Prophet. Even if this meeting never took place, this description remains one of a political meeting that could have really happened, at least in a similar way, but on the side of the imam in the presence of the author

68 A further rhetorical phrase: min al-nakāli wa-l-qatli wa-ibāhati l-amwāli: a climax with a longer third element and a rhyme in the first and third element.

69 Sabr "patience, or endurance" was among others a tribal value. Consequently for the people alȘaqrī/Ibn Di'tham addressed the positive meaning was immediately understandable (cf. Lane, An Arabic-English Lexicon, 1644c).

70 Wa-ḥaḍ̣ahum 'alā l-șabri wa-l-istiqāmati 'alā madhhabihim wa-l-mudāfa'ati 'an dīnihim wa-lmuhāfazati 'alā 'aqīdatihim: enumeration with parallelism. 
with the necessary few changes. With this story alone it is impossible to fully answer these questions. But at least the place-names are certainly not invented, and violent conflicts between these enemies are also known from other sources, as is the general historical and geographical context. The author then turns to the climax of the story:

They had not yet dispersed again from their meeting place when God the Exalted caused (ansha'a) a cloud to rise, and from that cloud pelted them with a punishment never seen at that time. A violent wind ${ }^{71}$ with ice/hail (barad) came down on them, which did not go beyond the borders of the village (balad) where they had met. It destroyed the agricultural lands and uprooted the crops, the wines, the trees and the fruits. ${ }^{72}$

Ibn Di'tham makes it very clear that God is the author of this catastrophe, indicating that the doctrines of the Mutarrifiyya are false. He then adds a couple of sentences in which he points out how the local people interpreted and understood what had happened:

It was a clear sign ( $\bar{a} y a$ zăhira) for the people of that village; they saw in it an evil omen (tațiru bihi) and they knew that they had been hit with His intention.

The story ends with the defeat for the Muțarrifi activist; people turn against him and drive him from their territory.

The ice [barad $]$ remained on those trees that were left in that area for three days. A group of the local population repented and recognised the greatness ( $f a d l)$ of the imam, peace be on him. After that, this evil one [al-Șaqrī] did not stay on except for some few days and then they expelled him from their lands.

The story is clearly meant to serve as an example ${ }^{73}$ and an argument for the imam's side against the Mutarrifiyya. If the people of al-Ahnūm had expelled the Mutarrifi in the first place, they would not have suffered the catastrophe. The moral of the story is clear: those who say that God does not create natural phenomena are wrong. They are punished by God with a natural disaster which clearly could not be mere coincidence. What is especially interesting is how the rather complicated and high-level theological differences are communicated in ways which ordinary - or

71 Reading hạșib instead of șāhib ("companion") in the text. See also the editor's note referring to hășib as denoting "a violent wind that raises the pebbles" and "a wind casting down pebbles from the sky: or a wind that tears up the pebbles. [...] And hence, A punishment from God [Lane cites alZabīdī, Tāj al-'arūs]" and "Clouds (saḥ̄âb) casting down snow and hail", Lane, An Arabic-English Lexicon, 581c.

72 "Fruits", thimār, could also be used metaphorically and translated as "yields".

73 In the year 1073/1074, in the biography of the two amirs al-Qāsim and Muhammad, the sons of Ja'far b. al-Imām al-Qāsim b. 'Alī al-'Iyānī, a similar case of punishment of opponents by hail, in that case the defeated army of the Șulayhiids, is reported. Cf. al-Raba'ī, Sirrat al-Amirayn, ed. alSayyid and 'Abd al-'Āṭī, 230. 
shall we say: ordinary but intellectually interested - people can understand. The author tries not only to describe the theological arguments, but also to convince the reader of the other party's error and the danger in believing the theory of natural causation. His account is clearly political propaganda for the imam and his version of theology, and consequently also his version of orthodoxy and his authority.

After this incident, the biographer describes other "steps" in the repression of the Mutarrifiyya during the following years, and the gradual territorial and hegemonial occupation by the imam. This is often related in more realistic language, such as the attacks on the two main centres of Muțarrifì life and learning, Hijrat Qā'a and, a few years later, Hijrat Waqash south-west of Sanaa in 1215. The Mutarrifiyya seems to have suffered under the imam's rule during the following years and was unable to recover after his oppression for several reasons, few of which are well-researched, but it lies outside of the scope of this chapter to explore them here. ${ }^{74}$

\section{Conclusion}

This chapter does not deal with a typical text regarding the End Times in the usual sense. Nowhere in the story of the hail-storm is anything like an end of time or signs of its approach mentioned. However, natural events were interpreted as a kind of end times for a specific group, the Muțarrifiyya. For the Muṭarrifiss, their declaration as unbelievers by the imam, and the ensuing killings, confiscations, and more or less violent conversions were the prelude to the movement's end. On the other hand, natural events like the hail in our story could have been interpreted as disasters announcing the end of the world, and it is telling that this possibility was not used by the people at that time. A feeling of an end of time or of the world, of the yawm al-qiyāma, was simply uncalled-for at that time, it seems. For the Mutarrifis God does not interfere with nature, at least not habitually, so there is no need to interpret the hail-event as a sign of the End Times, whereas for the other side, the imam, the hail is a sign for his close connection to God and an indication of his being the rightful imam. An interpretation of the hail as a sign of the end of the world is equally impossible for him.

We have several good studies of the theological disagreements and developments in this period, but there are few that examine how these advanced and abstract theories were simplified, popularised, and reduced to effective political slogans, rendered useful for the creation of communities and - at the same time - the creation of hierarchies and boundaries. This requires a repertoire of concepts outside of theology (and eschatology) itself, in which one can describe and model the social-political context as well as the theology/ideas and the channels and modes in

74 The most detailed account of the later years of the Muṭarrifiyya is given by Zayd, Tayyārāt, 156198. 
which they were communicated and expressed. For such an undertaking it is arguably necessary to use a wide range of sources, not only those that are considered theology.

Slogans like "the people of the strike" (ahl al-qafkha) are not effective by themselves, of course, but have to be contextualised within the specific political tensions at the time. We also have to take into account that different actors have different degrees of interest/capacity in theology, yet they are also at times forced into taking a position and to using religious doctrines as political demarcations. We know that Imam 'Abdallāh b. Ḥamza tried to expand his area of political influence and military dominance west into the fertile mountains of al-Ahnūm and wanted the population there to pay taxes to him. The Mutarrifiyya was also known to partially collect religious taxes such as zakāt, but they distributed this income locally, a policy we have to assume was more popular than paying taxes to the imam, who would then spend them mainly on war or on his allies. The Mutarrifiyya did not claim political hegemony over an extended region as the imam tried to. For example, they did not demand military conscription or support for holy war as the imam did from many of his subjects. The imam's intended take-over of al-Ahnūm was thus not only a matter of theology and orthodoxy; it also came along with political ambitions and consequences. The community was not only a community of religious orthodoxy: it was also a community of political loyalty. It was a hybrid religious and political vision of community.

In their biographies, the Zaydi imams are often portrayed as having special ties to God. Imams could therefore possibly help create rain for farmers. Intercession is a very controversial topic not only in Zaydism, but in Islam in general, and the exact nature of a "miracle" is often left vague. If the imam is obeyed, rain and prosperity would come. But not everyone believed that.

\section{Bibliography}

\section{Primary Sources}

al-'Abbāsī al-'Alawī, 'Alī b. Muḥammad b. 'Ubayd Allāh. Sïrat al-Hādī ilā al-Ḥaqq Yahyā b. alḤusayn. Edited by Suhayl Zakkār. Beirut: Dār al-Fikr li-l-Ṭibā'a wa-l-Nashr wa-l-Tawzī', 1981. Aḥmad b. Șāliḥ b. Abī l-Rijāl. Maṭla' al-budūr wa-majma' al-buḥūr fí tarājim rijāl al-zaydiyya. Edited by 'Abd al-Raqīb Muțahhar Muḥammad Ḥajr. Sanaa: Markaz Ahl al-Bayt li-l-Dirasāt al-Islāmiyya, 2004.

Ibn Di'tham, Abū Firās. Al-Sīra al-Manșūriyya: Sīrat al-Imām 'Abdallāh b. Ḥamza 593-614 H. Edited by 'Abd al-Ghanī Maḥmūd 'Abd al-'Āțī. Beirut: Dār al-Fikr al-Mu'āṣir, 1993.

al-Hamdānī, al-Ḥusayn b. Aḥmad b. Ya'qūb. Sīrat al-Imām al-Manșūr Bi-Llāh al-Qāsim b. 'Alī al'lyānī. Edited by 'Abdallāh b. Muhammad al-Ḥibshī. Sanaa: Dār al-Ḥikma al-Yamāniyya li-lṬibā'a wa-l-Nashr wa-l-Tawzī' wa-l-I'lān, 1996. 
al-Ḥimyarī, Nashwān b. Sa'īd. Shams al-'ulūm wa-dawā' kalām al-'Arab min al-kulūm. Beirut: Dār al-Fikr, 1999.

Ibrāhīm b. al-Qāsim b. al-Mu'ayyad. Ṭabaqāt al-Zaydiyya al-kubrā: al-Qism al-thālith wa-yusammāa: Bulūgh al-murād ilā ma'rifat al-isnād. Edited by 'Abd al-Salām b. 'Abbās al-Wajīh. Sanaa, McLean: Mu'assasat al-Imām Zayd b. 'Alī al-Thaqāfiyya, 2001.

al-Laḥjī, Abūl-Ghamr Musallam b. Muhammad b. Ja'far. The Sïra of Imām Aḥmad b. Yahyāa al-Nāșir li-Dīn Allāh; From Musallam al-Lahjī’s Kitāb Akhbār al-Zaydiyya bi l-Yaman. Edited by Wilferd Madelung. Exeter: Ithaca Press, 1990.

al-Lahjī, Abū al-Ghamr Musallam b. Muḥammad b. Ja'far. Akhbār al-Zaydiyya min ahl al-bayt 'alayhim al-salām wa-shī'atihim bi-al-Yaman. Manuscript, Jāmi'at al-Imām Muḥammad b. Sa'ūd alIslāmiyya, MS no. 2449.

al-Raba'ī, Mufarrị̣ b. Aḥmad. Sīrat al-amīrayn al-jalīlayn al-Sharīfayn al-fāẹilayn al-Qāsim waMuhammad İbnay Ja'far b. al-Imām al-Qāsim b. 'Alī al- 'lyānī. Nașs tārīkhī Yamanī min al-qarn al-khāmis al-hijrī. Edited by Riḍwān al-Sayyid and Abd al-Ghanī Maḥmūd 'Abd al-'Āṭī. Beirut: Dār al-Muntakhab al-'Arabī li-l-Dirāsāt wa-l-Nashr wa-l-Tawzī', 1993.

al-Thaqafī, Sulaymān b. Yaḥyā. Sïrat al-Imām Ahmad b. Sulaymān 535-566 H. Edited by 'Abd alGhanī Maḥmūd 'Abd al-'Āṭī. al-Haram, Giza: 'Ayn li-l-Dirāsāt wa-l-Buhuth al-Insāniyya wa-lljtimā'iyya, 2002.

\section{Secondary Literature}

'Abd al-'Āṭī, 'Abd al-Ghanī Maḥmūd. al-Șirā' al-fikrī fĩ l-Yaman bayna l-Zaydiyya wa-l-Muțarrifiyya: Dirāsa wa-nușūṣ. Cairo: 'Ayn li-l-Dirāsāt wa-l-Buhūth al-Insāniyya wa-l-ljtimā'īyya, 2002.

Ansari, Hassan and Sabine Schmidtke. "The Literary-Religious Tradition among 7th/13th Century Yemenī Zaydīs: The Formation of the Imām al-Mahdī li-Dīn Allāh Aḥmad b. al-Ḥusayn b. alQāsim (d. 656/1258)." Journal of Islamic Manuscripts 2 (2011): 165-222.

Ansari, Hassan and Sabine Schmidtke. "The Cultural Transfer of Zaydī and Non-Zaydī Religious Literature from Northern Iran to Yemen (Sixth/Twelfth Century through Eighth/Fourteenth Century)." In Globaliztion of Knowledge in the post-Antique Mediterranean 700-1500, edited by Sonja Brentjes and Jürgen Renn, 141-166. London, New York: Routledge, 2016.

Chittick, William C. "Muslim Eschatology." In The Oxford Handbook of Eschatology, edited by Jerry L. Walls. Oxford: Oxford University Press, 132-150. Oxford University Press, 2008.

Dresch, Paul. Tribes, Government, and History in Yemen. Oxford: Clarendon Press, 1989.

Gingrich, Andre. Erkundungen. Themen der ethnologischen Forschung. Wien, Köln, Weimar: Böhlau, 1999.

Gochenour, David Thomas. "Towards a Sociology of the Islamisation of Yemen." In Contemporary Yemen: Politics and Historical Background, ed. B. R. Pridham, 1-19. New York: St. Martin's Press, 1984.

Gochenour, David Thomas. "The Penetration of Zaydi Islam into Early Medieval Yemen.” PhD thesis, Harvard University, 1984.

Günther, Sebastian and Todd Lawson, eds. Roads to Paradise. Eschatology and Concepts of the Hereafter in Islam. 2 vols. Leiden, Boston: Brill, 2017.

Heiss, Johann. "Tribale Selbstorganisation und Konfliktreglung Der Norden des Jemen zur Zeit des ersten Imams (10. Jahrhundert).” PhD Thesis, University of Vienna, 1998.

Heiss, Johann and Eirik Hovden. "Competing Visions of Community in Medieval Zaydī Yemen." Journal of the Economic and Social History of the Orient 59, no. 3 (2016): 366-407. 
Kruse, Hans. "Takfïr und Ǧihād bei den Zaiditen des Jemen." Die Welt des Islams 23/24 (1984): 424-457.

Lane, Edward William. An Arabic-English Lexicon, ed. Stanely Lane-Poole. Beirut: Librairie du Liban, 1863-1872.

Madelung, Wilferd. "al-Manșūr Bi'llāh.” In Encyclopaedia of Islam New Edition, ed. P. Bearman, Th. Bianquis, C.E. Bosworth, E. van Donzel and W.P. Heinrichs, 6:435-36. Leiden: Brill, 19602004 [1996].

Madelung, Wilferd. "al-Rassī, al-Ḳāsim b. Ibrāhīm b. Ismā'īl Ibrāhīm b. al-Ḥasan b. al-Ḥasan b. 'Alī b. Abī Ṭālib.” In Encyclopaedia of Islam New Edition, ed. P. Bearman, Th. Bianquis, C.E. Bosworth, E. van Donzel and W.P. Heinrichs, 8:453. Leiden: Brill, 1960-2004.

Madelung, Wilferd. Der Imam al-Qāsim ibn Ibrāhīm und die Glaubenslehre der Zaiditen. Vol. 1, Studien zur Sprache, Geschichte und Kultur des islamischen Orients. Neue Folge. Berlin: De Gruyter, 1965.

Madelung, Wilferd. "A Muțarrifi Manuscript." In Proceedings of the VIth Congress of Arabic and Islamic Studies, 75-83. Leiden: Brill, 1975. (Reprinted in Wilferd Madelung, Religious Schools and Sects in Medieval Islam, London: Variorum, 1985).

Madelung, Wilferd. "Muțarrifiyya." In Encyclopaedia of Islam, New Edition, ed. Bearman, P., Th. Bianquis, C.E. Bosworth, E. van Donzel and W.P. Heinrichs, 7:772-773. Leiden: Brill, 19602004 [1993].

Madelung, Wilferd. "Zaydiyya." In Encyclopaedia of Islam New Edition, ed. P. Bearman, Th. Bianquis, C.E. Bosworth, E. van Donzel and W.P. Heinrichs, 11:477. Leiden: Brill, 1960-2004.

Schwarb, Gregor. "Mu'tazilism in the Age of Averroes." In In the Age of Averroes: Arabic Philosophy in the 6th/12th Century, ed. Peter Adamson, 251-282. London: Warburg Institute, 2011.

Smith, Jane Idleman and Yvonne Yazbek Haddad. The Islamic Understanding of Death and Resurrection. Oxford: Oxford University Press, 2002.

Thiele, Jan. Theologie in der jemenitischen Zaydiyya: die naturphilosophischen Überlegungen des al-Hasan ar-Rașsāṣ. Leiden: Brill, 2013.

Varisco, Daniel Martin. "The Adaptive Dynamics of Water Allocation in Al-Ahjur, Yemen Arab Republic." PhD thesis, University of Pennsylvania, 1982.

al-Wazīr, Zayd b. 'Alī, Badr al-Dīn al-Ḥūthi and Muḥammad Sālim 'Izzān. Ḥiwār 'an al-Muțarrifiyya. Al-fikr wa-l-ma'sāt. Kitāb al-Masār. Sanaa: Markaz al-Turāth wa-l-Buḥūth al-Yamanī, 2002.

Zayd, 'Alī Muhạmad. Mu'tazilat al-Yaman: Dawlat al-Hādī wa-fikruhu. Sanaa: Markaz al-Dirāsāt wa-l-Buhūth al-Yamaniyya, 1985.

Zayd, 'Alī Muḥammad.Tayyārāt mu'tazilat al-Yaman fí l-qarn al-sādis al-hijrī. Sanaa: al-Markaz alFaransī li-l-dirāsāt al-Yamaniyya, 1997. 